\title{
Collaboration between Universities and Governments in Realizing Quality Policies, (Evidence-Based Policy)
}

\author{
Al Adly Darniyus ${ }^{1}$, Hardi Warsono ${ }^{2}$ \\ ${ }^{1}$ Magister of Public Administration, Diponegoro of University, Indonesia \\ ${ }^{2}$ Faculties of Social Science and Political Science, Diponegoro of University, Indonesia \\ Corresponding Author: aladlydarniyus@gmail.com ${ }^{1}$, hardie_wsn@live.undip.ac.id ${ }^{2}$
}

\section{Article Info}

\section{Keyword:}

Collaboration;

Evidence;

Policy;

University;

Kata Kunci:

Bukti;

Kebijakan;

Kolaborasi;

Universitas;

\begin{abstract}
Many underlying these gaps, including lack of information invalidity of the results of research of universities and is unable to improve the confidence government to accommodate the information. On the other hand, there are still the strong political influences in policy formulation. Lobby system, a compromise to the bargaining to determine whether the policy is decided or not decided. Therefore, this article aims to look at the university and government collaboration in producing quality policy. This paper uses Emerson's theory, there are three components in collaboration, principled engagement, motivation and capacity for action together. The writer uses the method of literature study, which collects data, information, by examining research journals, books, literature as well as a source of reliable sources both written and digital-related and relevant to this paper. The results showed that the university meets the three components in the theory. But in practice, the university has not been able to meet the needs of a quality policy. It is found from information and research of results that have not been able to open trust policy-makers. As a result, only a small input of research of results and more dominated by political interests. Therefore, one of the efforts that must be addressed is the government involved in designing the study.
\end{abstract}

Abstrak: Banyak yang melatarbelakangi kesenjangan tersebut, diantaranya kurang validnya informasi dari hasil penelitian perguruan tinggi sehingga tidak mampu meningkatkan kepercayaan pemerintah untuk menampung informasi tersebut. Di satu sisi, masih kuatnya pengaruh politik dalam perumusan kebijakan. Sistem lobi, kompromi sampai kepada tawar menawar untuk menentukan apakah kebijakan tersebut diputuskan atau tidak diputuskan. Oleh sebab itu, tulisan ini bertujuan untuk melihat kolaborasi universitas dan pemerintah dalam menghasilkan kebijakan berkualitas. Tulisan ini menggunakan Teori Emerson, ada tiga komponen dalam kolaborasi, yaitu penggerakan prinsip, motivasi dan kapasitas untuk melakukan tindakan Bersama. Penulis memakai metode studi kepustakaan, yaitu mengumpulkan data, informasi, dengan menelaah jurnaljurnal penelitian, buku-buku, literatur-literatur serta sumber sumber terpercaya baik tulisan maupun digital yang berhubungan dan relevan dengan tulisan ini. Hasil penelitian menunjukkan bahwa universitas memenuhi tiga komponen dalam teori tersebut. Akan tetapi dalam praktik, universitas belum mampu mencukupi kebutuhan kebijakan yang berkualitas. Hal ini ditemukan dari informasi hasil penelitian yang belum bisa membuka kepercayaan para pembuat kebijakan. Akibatnya hasil penelitian hanya masukan kecil dan lebih didominasi oleh kepentingan politik. Oleh sebab itu, salah satu upaya yang harus dibenahi adalah melibatkan pemerintah dalam proses perancangan penelitian, ini akan meningkatkan kepercayaan para pembuat kebijakan terkait informasi yang didapatkan.

Article History： Received; 2020-01-23 Revised; 2020-01-31 Accepted; 2020-02-22 


\section{INTRODUCTION}

Implementation of good government (good governance) into the hottest topics in developing countries, especially Indonesia. All resources are mobilized to realize good governance so as to reduce or even eliminate the violations in the public sector, such as collusion, corruption, nepotism, maladministration, buying and selling positions and others. Efforts have been taken by the government to the regions in the form of policies oriented towards the realization of good governance.

To establishment of a quality policy and to minimize violations of the above, then the governments can no longer work alone (single actor). However, the government must have a partner to bring quality policy options. Generally, control is retained by the government, but in the perspective of generating quality policy of the government is no longer the sole actor, though its existence becomes important in the decision of making unit (Winarno, 2008).

One of product policies demanded by the stakeholders is a policy that based evidence (evidence-based policy). Among the evidence that could be used as the basis for a policy are the results of research. The strength of the research of results can provide evidence of what support efficient and effective and what is inefficient and ineffective (Dewi, 2013). Through the results of these studies are expected policy-makers to consider or at least have the best options for product policy

Basically, policy with research has linear relationship. The research is used to fill the gaps identified through knowledge; evidence from the research will also provide a method to identify the best option from a few other policy options (Asmara, 2016). The presence of research in policy making will ultimately geared towards the needs of the public, on the other hand, the government also will not be seen as an actor who is only concerned with several parties.

Need of a policy towards the research has a fairly strong dependence. It is based on the purpose of evidence-based policy that is under pressure to tackle the problem systematically with the help of data, risk analysis, proactive response and identification (Subhan, 2019). As other countries (best practices) have been promoting the role of research in producing quality policy. For example, Canada, the UK, Uruguay and Vietnam, they illustrate the importance of research in support of the creation of a policy(Asmara, 2016). Moreover, the results of in-depth research can be a supporter of realizing product quality policy, the results of a research are basically found in a scientific way, the rational, empirical and systematic.

Seeing the two instruments (the results of a research and policy) are interconnected, they present a great opportunity for researchers, especially universities to cooperate in producing a quality policy product. However, it is also important to ensure that research results are easily accessible, understood and implemented by policy-makers so that can be useful in to the maximum. But if the uses of the results of improper or even misunderstand will produce ineffective policies.

University and government collaboration are a model of cooperation that has been built by the developed countries. An example of Finland, since 1970 had been using results of research as a guide for policy-making. One of results is finlandia had been reforming education into the curriculum form (Sahlberg, 2011). Even Malaysia had been collaborating with the government's performance-related university policy-making. The result of Malaysia was able to build regional areas (Afzal et al., 2017).

Collaboration of researchers (one of universities) and the government had been mandated by Law No. 12 of 2011 Concerning the Establishment Regulation Legislation stating that should involve researchers. There is the opportunity to produce a product quality policy will be easier because there is scientific data support the results of research.

Seeing the contributions made on college-related evidence or data provided, appear to influence the course of policy. Although the information provided cannot be fully used as a benchmark, but consideration for the results of university of research has a major impact. So in this article, the authors focus on university and government of collaboration in producing a quality policy. 


\section{A. Public Policy}

In brief and general Anderson, Howlet and Ramesh summarizes several definitions of public policy, is as follows:

a) Thomas Dye interpret as any public policy chosen by the government to do or not do

b) William Jenkins looked at as a set of interlocking decisions taken by a political actor or group of actors concerning the selection of goals and ways to achieve certain situations where the decision in principle at the mercy of those actors to achieve it.

c) James Anderson has described the policy as a deliberate action followed by an actor or set of actors in dealing/resolve problems or issues of concern.

d) Howlet and Ramesh define policies as a complex phenomenon consisting of various decisions made by many individuals and organizations.

Some of the above definition, public policy is a series of policy decisions taken by a person or group of people to achieve certain goals in society (Taufiqurokhman, 2014).

\section{B. Evidence}

Globally, evidence is regarded as findings in the field. What happened is a proof coupled with some paperwork/documentation. Cabinet Office Britain cited in (Marston \& Watts, 2003), the evidence includes "expert knowledge, published research, available statistics, consultation with stakeholders, evaluations of previous policy, the internet, the result of the consultation, the count the cost of the policy options and outcomes of economic and statistical modeling.

There are differences among the various relevant evidence. Therefore, following the author describe different definitions of evidence for a policy-maker and a researcher.

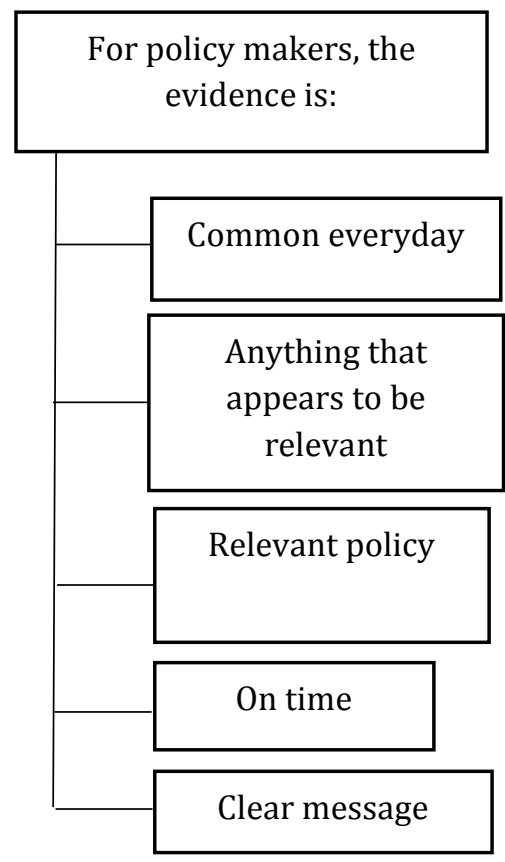

Describe different definitions of evidence for a policy-maker and a researcher Source: (Bachtiar, 2011)

Then, there are two main forms of evidence required in this approach to increase government effectiveness. First, the evidence to promote accountability in the event that is evidence the government is working effectively. Second, the evidence to promote increased through a policy or program that is more effective. Meanings, policies or programs that work under different conditions (Sanderson, 2002). 
The relationship between research and policy is still far from optimal. It is viewed as temporary and gradually continue to change (Hunter, 2009). Therefore, at least some of the reasons why the research of evidence has little impact on public policy, as follows: (Black, 2001)

a) Policy-makers have a purpose other than the effectiveness of the (social, financial, strategic development of services, terms and conditions of the employees, the general election)

b) The research evidence is irrelevant (of a sector or a different specialization, practice depends on tacit knowledge, does not apply locally)

c) The lack of consensus on the research evidence (the complexity of the evidence, the scientific controversy, a different interpretation)

d) This type of evidence other competing (personal experience, local information, opinion leading peers, medicolegal report)

e) The social environment is not conducive to policy change poor quality of knowledge providers

\section{Collaboration}

Public management has been transformed into participatory governance, involving the private sector, communities and governments. Collaboration means cooperation, interaction, compromise of some relevant elements (individuals, groups, institutions), which will receive the result and benefits. There are several elements of collaboration in the research context; the element is used as an analytical tool and focus research to answer the collaboration of government, namely:
a. Motivation
b. Interdependency or Codependency
c. Trust or legitimacy of the Internal
d. Leadership
e. Common goals
f. Basic Rules Collaboration
g. Consensus
h. Commitment to Process
i. monitoring
j. Cooperation history
k. Participation
l. Transparency

There are three components contained in the collaboration of government, namely the principle of collective mobilization (principled engagement), motivation Commons (shared motivation) and capacity for action together (capacity for joint action) (Emerson et al., 2012). This theory I use for these three components relate to government collaboration with the university as a research institution. Then university is also able to provide evidence of the results of research to provide the best policy option.

\section{RESEARCH METHOD}

This paper uses literature study method, which collects data, information, by examining research journals, books, literature as well as a source of reliable sources both written and digital-related and relevant to this paper. Descriptive analysis was used to identify and expose the various problems in the production of policy through research in Indonesia. This paper examines the phenomenon, challenges and potential will be given if adopts evidence-based policy. Then the author also tries to explore the lessons learned from the existing references in order to look for an alternative in providing product-quality policy. 


\section{RESULT AND DICUSSION}

Policy with quality approach is a desire of every government. Therefore, the size of the quality policy is not merely at the conceptual, but it located at the end of the policy (output). Government performance in realizing the quality policy is difficult and complex. A long process as well as being political activities should certainly involve many parties. In the process the government should take collaboration to realize the quality policy. The collaboration will lead to all parties will be a strong accountability and rational for the final achievement of the so-called Impact. Breaking through to the final costs and a long time, so that government cannot impose to walk alone.

Collaboration generally helps the government more efficient and focus to understand the context of the policy will be taken. The collaboration will also help the government to find accurate information. One of the stakeholders who have an important role in the realization of quality policy is the university. The involvement of the university should serve as the backbone of the birth of a quality policy on the basis of evidence, knowledge base and base public expectations.

The presence of the university as a research institution, it would be much a positive impact in achieving the output so inefficient can be minimized. Even the contribution of the university to the government as well as to emphasize the principle of the benefit, problem solving and vigilance in the future.

According to the theory used in this article, that there are three components contained in collaboration according to Emerson, Nabatchi and Balogh, the Principled Engagement, motivation and capacity for join action. Through these three components, policy-makers and universities have in common, especially in producing quality policy.

\section{A. Principled Engagement}

Many stakeholders can be invited to collaborate by the government. But in the context of evidence-based policy, the university became the leading stakeholders. In addition to being legal drafting at this stage of the policy, the university is also able to provide the results of scientific research once scientists gathering place. Then university is a measure of human resource development in Indonesia, scoring many academics and practitioners who have a background of expertise, professional capacity and specialists. Therefore, the university serves as one of the products of machine via the distribution of public policy professionals.

In the context of the Principled Engagement, the university has the same importance, especially related to the research community. University emphasizes the discovery of the problem and seeks to provide an alternative to the settlement of the problem. Meanings, evidence of field is a basic argument of university to collaborate with policy makers. Emerson, Nabatchi and Balogh also said that not only the formation of deliberations, but there should be signing on the quality of deliberation. This indicates to the university if the collaborating is that results of research must be qualified, so as to open up the confidence to policymakers for further analysis.

Through the principle of this university, the course will provide a big enough impact for the local community. Therefore, as a means to solve the problem, the university must analyze with policymakers. The analysis process should know the advantages and disadvantages that would be obtained if it is implied. The end of this Principled Engagement, that the universities and policy-makers must determine the result of collaboration products. For example, collective agreements, the final recommendation of collaborating action.

The power to decide quality policy views of the mountain of evidence found. Among the evidence that must be considered is the evidence of the results of research (evidence-based policy). Universities in this case have the principle that any research to be conducted and the research that has been done should be tested for validity in theory and scientific method. Based on the above linked mobilizing the principle adopted by the university, shows that the university has a strong and sustainable principles with the goal of policy makers that solve social problems. 


\section{B. Motivation}

In this motivational aspects, policy makers and university should have a relational and interpersonal from the collaboration that is often disbud as well as social capital. This motivational component contains mutual trust. Policymakers and universities must have mutual trust on the duties and responsibilities given. Policymakers should be able to open up the belief that research conducted by the university is valid and scientifically. If it has not been able to increase the confidence of policy makers, the next step is to give assistance to the university. The goal is to research carried out in accordance with policy priorities and receipts powerful method. In addition, assistance will also reduce fraud and plagiarism. When trust has emerged, then to understand than any policy analysis will be higher quality. That understanding is interpreted in collaboration components namely mutual understanding.

Motivating force universities to produce quality research results as well as the motivation of policy makers that produce quality policy. Motivation universities in research can be reviewed through journals that accredited such as the table 1 the journal publications may be understood that the results of university research have been categorized as quality. Therefore, the university component is sufficient motivation to do collaboration with the government (policy-makers).

\section{Capacity}

Universities generally have sufficient capacity, especially in human resources. The same as with the research, the university officially produces research, sustainable once the responsibility of each university to produce new findings. The capacity to produce research is one of the major progresses of each university. In addition to producing the study, every university is also required to publish research results in journals accredited national or international journals of repute. This demand is a requirement to improve the reputation of any university in the national and international levels.

Judging from the capacity of the university, should policy-makers both national and local levels should do collaboration with the university. There are several elements that should be considered relates to components of this capacity, Emerson, Nabatchi and Balogh again split criteria that must be held in order to establish a good collaboration. These criteria are procedures and institutions deal, leadership, knowledge and resources. Four criteria are already owned by the university as an educational institution.

Based component collaboration capacity in the university seems more feasible to collaborate with policy makers. It also is causing many countries to collaborate with universities to find the best policy.

Through the above three components, a collaboration of government (policy-makers) with the university should go well because it is a model of effective performance. Many of the benefits that policy-makers get through the collaboration. For example, the university has the human resources to carry out a policy analyst. Because the university is an association of scientists that have been scientifically proven ability. In another aspect of policy-makers will be more efficient to be issued related to the budget, since the university annually will produce a study. Even these studies are the responsibility of each university as well as to improve the rating of the university.

Seeing so many advantages gained by policy-makers, many countries have been collaborating with the university. Wales's government (policy-makers) has been able to improve service delivery innovations, economic development in the world of business through the best policy based on collaboration with universities. The state of Parana, Brazil is also collaborating with the university. The results showed that the development of innovation received financial resources and provided information about management process. The Malaysian government has also done collaborations with universities, the results have an impact on regional development better, the increased commercialization of technology, innovation and industrial products (Afzal et al., 2017). Some best practice above shows that government collaboration with the university promising success of a policy. One of hopes of 
collaboration to the university is the university is able to find evidence of field accurately. So that the evidence can be useful to policy-makers.

At least, there are several reasons why many developing countries / developed that make the university as a foundation to produce quality policy. First, the university is able to provide accurate information with the power of his research. Second, the university is able to provide data to the government, to assess whether there is a policy that should be evaluated or even requires new policies to address public concerns, and third, the university is able to sustain the strength of the professional government.

In Indonesia, collaboration with university policy makers continue sounded. 2019 Minister of Administrative Reform and Bureaucratic Reform (MARB) have stressed that there should be a university involvement in the decision to encourage quality policies and governance professionals. Therefore, it is expected the great teachers participated in collaboration with the government. MARB also said that the university has a major role, including communication to bridge the birth of public policy through research or surveys that direct contact with the community while providing a solution to social problems.

The public policy process in Indonesia, the university is often ignored in the policy process, especially the utilization of research results. This means that there is mistrust between policymakers with research results from universities. When viewed from a different angle, it was distrust to the results of research universities. The cause is a lack of focus on the quality of university research results. As a result, are not able to recommend to policy-makers. Therefore, the university should give particular attention to the results of research to be able to recommend an evidence-based policy.

One of efforts to improve the quality of research results and increase the confidence of government is to involve the policy makers in the design phase of the study. Assistance policy makers in the research process will affect the course of the study. Starting from the budget, research methods to the presentation of research results. It will be more accountable and rationally to the study, but in maintaining independency status of research. Government involvement is only to drive research that later research results are relevant to government policy priorities.

Models such assistance, has not seen clearly in the realm of the university. Not only is policy-makers, but also university (lecturer and others) is than facilitating accurately during the research process. Consequently, the results obtained may be biased or even a mere formality to complete tasks and responsibilities. Sometimes you cannot also discredited the policy-makers about the lack of cooperation or involvement of universities in generating policy. Due to the perspective of policy-makers are generally wider than the researcher. Policy-makers will consider other aspects such as politics, society's response estimates and resource availability.

\section{Quality of University Research}

Educational development at the international level into the arena of the strongest competition than other aspects. One of them is how to improve the reputation of a university in the national and international levels. Because the university is regarded as the highest educational institution and able to produce human resources that have the nation's competitiveness. In human capital theory also explained that the advantage of the university as an institution of education and training is a form of investment in human resources (Muyia Nafukho et al., 2010). In fact, history records that countries are implementing the development paradigm of human resource dimension has been able to grow more quickly despite not having rich natural resources are abundant (Dwi Atmanti, 2005).

In the university context, one of measures of priority in improving the reputation of the university is to produce research-quality research. Excellence research is a source of competitively excellence that will help improve the reputation of the university (Wibowo, 2014). Excellence produce quality research results should also be able to publish or publish in journals accredited national or international journals of repute. Here are some results of the study who received the award from the Science and Technology Index (Sinta) in 2019. 
Table 1

Recipients Sinta Award in 2019

\begin{tabular}{|c|c|c|}
\hline No. & Name of College / Institution & Category \\
\hline 1 & Institute of Technology & The best writers (first rank) \\
\hline 2 & $\begin{array}{l}\text { Bandung Institute of } \\
\text { Technology }\end{array}$ & $\begin{array}{l}\text { The best writers (second } \\
\text { rank) }\end{array}$ \\
\hline 3 & Gadjah Mada University & The best writers (third rank) \\
\hline 4 & $\begin{array}{l}\text { Bandung Institute of } \\
\text { Technology }\end{array}$ & Best institutions (first rank) \\
\hline 5 & University of Indonesia & $\begin{array}{l}\text { Best institutions (second } \\
\text { rank) }\end{array}$ \\
\hline 6 & Institute of Technology & Best institutions (third rank) \\
\hline 7 & Yogyakarta State University & Best journals (first rank) \\
\hline 8 & $\begin{array}{l}\text { Specialist Doctors Association } \\
\text { of Indonesia }\end{array}$ & Best Journals (second rank) \\
\hline 9 & Semarang State University & Best journals (third rank) \\
\hline
\end{tabular}

Source: Ristekdikti, 12 September 2019

At the national level on the top, the results indicate that the actual published many research results of universities that have quality. This means that capital towards research university with a strong method, a clear theory and research and systematic design can be realized. This strength is certainly able to break down the needs of policy (evidence-based policy). In Table 1 explains that in 2019 there were some of the results of scientific journal publications proven that given the award to the parties concerned.

There is some impact given when the results of the university found. First, each quotation among academics. Foothold to conduct another study conducted by pengutip easier because the data or information already listed in the previous study. Second, the results serve as scientific publications to enhance the university's reputation as well as to qualify as a professor and others. Third, as a recommendation to the government, in order to realize the welfare of society.

In the third phase of the above, a lot of research that can be referenced as a policy decision. For example, research by the discipline of science, health, legal and social. As an example of the standardization policy-making equipment and Agricultural Engineering (Agricultural Machinery) is an evidence-based policy. The formation of connections between representatives of their respective interests in the manufacturing process of the Indonesian National Standard (INS) Alsintan. The involvement of all the parties makes effective policy implementation has begun, must be carried out increased surveillance by various stakeholders (Anugerah Yuka \& Handoyo, 2015).

On the other research about social justice in the palm oil sector in Indonesia, which also has led to evidence-based policy. Policy has been supporting the local community both women and men to develop the capacity of oil palm plantations (Li, 2018). So is the case with health policy that has been referred to the evidence. Among the study drug prices, the new vaccine studies, studies of resuscitation of newborn infants with asphyxia and others (Kosen, 2011).

\section{E. Quality Policy}

Less than quality policy in Indonesia is a reflection of situation of the country. One of the reasons behind the lack of a policy in the form of regulation is weak supporting data. Data should be the initial information needed by the government in policy making, even such data is the primary requirement of a product policy. The university's participation in the decisionmaking process is a step to obtain valid data. However, data from the results of university research is often regarded as a small input and information / news-related problems in society. Whereas in the concept of evidence-based policy, the results of such research to fill gaps identified through knowledge, which eventually study is able to provide policy options.

The research is not the only evidence to formulate a policy. Many other considerations that must be put forward as a strategic adjustment, ideological messages, accountability and 
others. The consideration to be able to minimize the threat and risk policy implementation. But the practice in Indonesia, a policy change is quite easy to do. For example, when there is a cabinet reshuffle, a policy will also change (Head, 2008). These conditions are triggered because every minister is required to work. Although previous policy already has a good value in society, if the government conditions like this, it can directly be given an assessment that the policy is not based on the interests of the people.

Identified three lenses (three lenses) as the understanding of the evidence base for policy making quality, namely scientific knowledge, political knowledge and knowledge of practical implementation (Head, 2008). Three forms of policy analysis are often also debated by the university and the government, so often there is a clash of perspectives in the policy formation process.

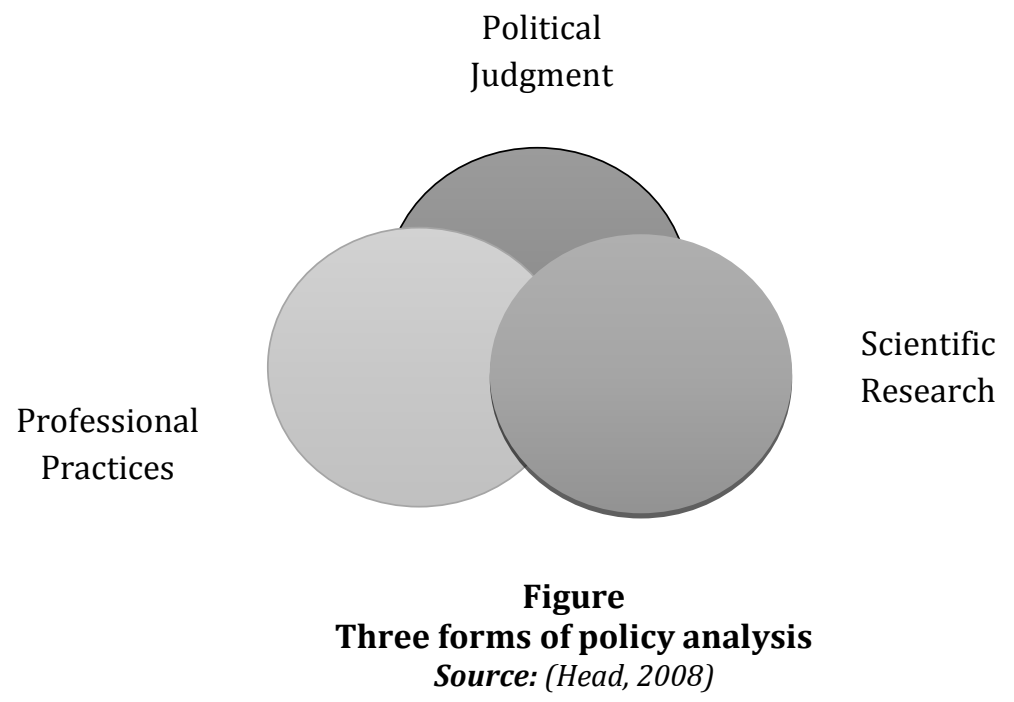

\section{a) Scientific knowledge}

University produces the research called scientific knowledge. It is scientifically recognized due to research compiled systematically, using appropriate theory of science and the scientific method. Most studies also use quantitative methods with various hypotheses and causation which will affect the course of the study. There are some research results of the disciplines can contribute to formulating related policies, such as the economy, public administration, law, sociology and others. These disciplines have a positive impact in the decision making, both in terms of problems found, program analysis and evaluation, the cause and the relationship to the best solutions offered.

The scientific knowledge also involves professional people among universities; there is also a major job and so on. Approach to the quality of the end result of a study. However, not all research can adequately policy needs. Source out information provided has not been able to convince the policy makers to adopt it. Even many of the universities produce a study with no apparent design as well as using weak (Bachtiar, 2011). As a result, there is a failure of the results of research in policy formulation.

\section{b) Political knowledge}

Sometimes the role of the political elite as the main actors in decision-making. Lobby system, compromise, bargaining that led to the purchase of a policy occurs in the realm of politics. Quality policy is not a consideration, but a policy based on public opinion, politicians feeling, intuition and certain interests must be a top priority for political actors. Political conditions that tend to see such evidence (research) it is difficult to qualify as an alternative to policy making. In addition, it is also necessary to understand that the policy is a political process that cannot be separated, so that other aspects only limited support or just information. 


\section{c) Practical Implementation Knowledge}

The actor who became executor of the program is the ones who understand the situation. They deal directly with the actors of policy-makers, researchers, institutions and society. Their involvement in policy formulation as important as the involvement of universities. These two elements are the practical executor, one of the hallmarks of the practical is every day they immediately feel the good or poor implementation of the program, even able to predict things will come because it compares from past program, plus data and events continue to grow.

\section{F. Government and university of Collaboration}

Referring to Law No. 12 of 2011 Concerning the Establishment Regulation Legislation, that the researcher is one of the actors who should be involved in policy making. It is viewed as researchers were able to produce strong evidence. Although the evidence from the research is not the only major evidence in policy making, but the policy is not based on evidence from research results would adversely affect the implementation of a policy.

Many policies have been based on evidence (research) as some of the cases described above, but no less important is a policy that is not based on evidence. It is especially in the context of research in the social sciences who do not get the privelege by policymakers (Anugerah Yuka \& Handoyo, 2015). Whereas, in the perspective of the state administration that the public policy of multidisciplinary, then mulitdisiplin approach needs to be considered as a policy analyst knowledge, disciplinary backgrounds and so forth.

The cause of the lack of such privilege is policymakers to define a research as the information is inadequate and less established. This led to the inevitability of public debate due to Adaiah misinformation. Therefore, every scientist and researchers kept up-to focus on the information provided to policymakers (Dicks, 2013).

Bond college to obtain valid information that lies in the capacity of university resources, because it will affect the course of the research process. There is no guarantee that the title of professor has a good capacity to produce a study. Other conditions also occur in the university that there are many professors at each university, but more than half of the professors just as support personnel. Lecturer only focused on teaching and other activities outside the campus. This condition also occurs in several research institutions, consequently the results are less qualified. It is important to pay attention to extracting information, validating the data to convince policy makers that the results of these studies really are.

Actually, government openness to accommodate the performance of universities as producers of research is the right choice. University in moving the concept of evidence-based policy specifically to fight the scientific evidence. On the other hand, the movement of evidencebased policy emphasizes the government that the public problems (practical problems) requires a comprehensive literature and relevant to the policy will be decided. This concept will identify what is most relevant to public issues resolved effectively and efficiently (Young et al., 2002).

Indeed, to reach the stage of proof of use (research) as a policy basis required political nature of policy making. Political nature of the policy is recognized because it involves a compromise between agencies in various competing interests. The political process is structured, has a specific institution that is capable of forming or may limit a policy to be decided, including dictating policy makers. All these are efforts made to ensure that policies decided or not decided. The factors that cause why the evidence (research) of the university has not been able to tell which option is the right to policymakers. Because of the policy on the basis of evidence should re-consider social values,

In addition, the government also often associated with decision-making based on intuition and compromise, the collaboration with the university will enhance the professional image of the government. Despite what the policy-makers do not break the rules and norms, but the model of such an approach does not guarantee their public benefit and increase public confidence.

The above situation illustrates to the public that the miscommunication between policy makers and universities. Gaps between policy makers at the university led to a lack of 
communication so that there is a vacuum of information in the midst of the government as policy maker. Automatically sustainability of university research is no longer relevant to policy priorities (Parkhurst, 2017). In fact, with the collaboration of government, university and other policy actors can at least use a mode of knowledge transfer. The aim is that every policy analyst is able to calculate, consider each sector (cultural, social, economic, and public institutions).

Through collaboration between policy makers and the university turned out to provide a tough challenge to the university. Universities under pressure from interest groups, political values and culture of bureaucracy is thick. The amount of friction, as a result of any institution/institutions closed mutually related data and information, because they interfere with the performance of agencies/institutions. Closing of information in various institutions is one cause of the difficulty of generating quality research. Barriers with major influence motivation, performance and research results obtained by the university.

Therefore, the government collaboration with the university becomes important role that must be built. Involving other public sectors so that there is ease of access, gather information and identify parts of the information most relevant to policy priorities. The results of the involvement of various parties are universities more flexibility and motivated to do effective research. Back to the theory of Emerson, Nabatchi and Balogh that I use, that the university has a clear eligibility to collaborate with policy makers, and all forms of given criteria, unviersitas has completed a systematic manner. Therefore, establishing collaboration with the university is the best solution to obtain quality evidence-based policy options (evidence-based policy).

\section{CONCLUSION}

The result of the above discussion shows that the university has not been able to meet the needs of a quality policy. That is not the realization of an effective collaboration between universities and governments This is because the results of university research did not consider the values of social, cultural, legal and so on as well as information unearthed very often less valid. As a result, policy makers rarely use the results of these studies as the basis of evidence in policy-making. in addition to the weakness in the sector, the political power behind the scenes also be different causes of why the various studies received less attention. Therefore, policy decisions are dominated by political interests and research results just a little input from policy formulation.

As a country that wants to realize good governance, the policy makers can no longer work alone. The need for an external party (college) as a battering ram-quality policy. Then the government should provide assistance in designing the research to the test to a study. This model would be more effective to reduce the gap between the government and universities. The involvement of universities in policy making has been realized, but what about the government's involvement in the design process research should also be realized. Not just give a budget, but monitoring and quality of research results must be put forward.

\section{REFERENCE}

Afzal, M. N. I., Dutta, S., Mansur, K. B. H. M., \& Lawrey, R. (2017). Practice of Triple Helix (TH) Model in Malaysian Research Universities (RU). 10(2), 90-104. http://dx.doi.org/10.12695/ajtm.2017.10.2.4

Anugerah Yuka, A., \& Handoyo, S. (2015). Pembuatan Kebijakan Berbasis Bukti: Studi Pada Proses Pembuatan kebijakan Standardisasi Alat dan Mesin Pertanian di Indonesia. Warta Kiml, 13(1), 56-57.

Asmara, A. Y. (2016). Pentingnya Riset Kebijakan Dalam Pembuatan Kebijakan Publik Unggul Di Indonesia. JPSI (Journal of Public Sector Innovations), 1(1), 37-46. https://doi.org/10.26740/jpsi.v1n1.p37-46

Bachtiar, P. P. (2011). Menghasilkan Bukti Sebagai Informasi Bagi Proses Penyusunan Kebijakan di Indonesia: Tantangan Pada Sisi Penawaran (Nomor 32: 7).

Black, N. (2001). Evidence based policy: Proceed with care. BMJ: British Medical Journal, 323(7307), 275-279. https://doi.org/10.1136/bmj.323.7307.275 
Dewi, S. L. (2013). Dapatkah Kita Berperan Serta Menjawab Tantangan Kebutuhan Kebijakan Berbasis Bukti? Jurnal Kebijakan Kesehatan Indonesia: JKKI, 2(3). https://doi.org/10.22146/jkki.v2i3.3206

Dicks, L. (2013). Bees, lies and evidence-based policy. Nature News, 494(7437), 283. https://doi.org/10.1038/494283a

Dwi Atmanti, H. (2005). Investasi Sumber Daya Manusia Melalui Pendidikan. Jurnal Dinamika Pembangunan (JDP), Volume 2(Nomor 1), 30-39.

Emerson, K., Nabatchi, T., \& Balogh, S. B. (2012). An Integrative Framework for Collaborative Governance. Journal of Public Administration Research and Theory, 22. https://doi.org/10.1093/jopart/mur011

Head, H. (2008). Three Lenses of Evidence-Based Policy-Head-2008-Australian Journal of Public Administration-Wiley Online Library. https://onlinelibrary.wiley.com/doi/abs/10.1111/j.1467-8500.2007.00564.x

Hunter, D. J. (2009). Relationship between evidence and policy: A case of evidence-based policy or policy-based evidence? Public Health, 123(9), 583-586. https://doi.org/10.1016/j.puhe.2009.07.011

Kosen, S. (2011). Peran Peneliti dalam Proses Kebijakan. Pusat Humaniora, Kebijakan Kesehatan dan Pemberdayaan Masyarakat-Badan Penelitian dan Pengembangan Kesehatan. Kementerian Kesehatan R.I.

Li, T. M. (2018). Prioritas Penelitian, Kebijakan dan Advokasi Berbasis Bukti untuk Mendorong Keadilan Sosial di Sektor Kelapa Sawit Indonesia. Http://Www.Cifor.Org/. https://doi.org/10.17528/cifor/007015

Marston, G., \& Watts, R. (2003). Tampering With the Evidence: A Critical Appraisal of EvidenceBased Policy-Making. 3(3), 21.

Muyia Nafukho, F., Hairston, N., \& Brooks, K. (2010). Human capital theory. https://docplayer.net/50891040-Fredrick-muyia-nafukho-a-nancy-hairston-kit-brooksa-university-of-arkansas-published-online-12-dec-2010.html

Parkhurst, J. (2017). The politics of evidence: From evidence-based policy to the good governance of evidence-LSE Research Online. http://eprints.lse.ac.uk/68604/

Sahlberg, P. (2011). PISA in Finland: An Education Miracle or an Obstacle to Change? Center for Educational Policy Studies Journal, 1(3), 119-140.

Sanderson, I. (2002). Evaluation, Policy Learning and Evidence-Based Policy Making. Public Administration, 80(1), 1-22. https://doi.org/10.1111/1467-9299.00292

Subhan, H. (2019). Evidence-Based Policy And Practice: Tantangan Dan Pengembangan. JISPO : Jurnal Ilmu Sosial Dan Ilmu Politik, 9(1), 82-96. https://doi.org/10.15575/jispo.v9i1.4499

Taufiqurokhman, T. (2014). Kebijakan Publik Pendelegasian Tanggungjawab Negara Kepada Presiden Selaku Penyelenggara Pemerintahan. Beragama Pers. http://archive.org/details/KebijakanPublikOlehDr.Taufiqurokhman.M.Si

Wibowo, A. J. I. (2014). Kinerja Riset Universitas, Reputasi Universitas, dan Pilihan Universitas: Sebuah Telaah Sistematis. Jurnal Manajemen Maranatha, 13(2). https://doi.org/10.28932/jmm.v13i2.129

Winarno, B. (2008). Politik Regionalisme Dan Tantangan Asean Di Tengah Arus Besar Globalisasi. SPEKTRUM, $5(2)$. https://publikasiilmiah.unwahas.ac.id/index.php/SPEKTRUM/article/view/487

Young, K., Ashby, D., Boaz, A., \& Grayson, L. (2002). Social science and the evidence-based policy movement. Social Policy and Society, 1(03), 215-224. 